\title{
A TANÁRI NÉZETEK \\ ÉS AZ OSZTÁLYTERMI INTERAKCIÓ ÖSSZEFÜGGÉSEI KUTATÁSI EREDMÉNYEK TÜKRÉBEN
}

\author{
KARDOS MELINDA \\ a Babeş-Bolyai Tudományegyetem Szatmárnémeti Kihelyezett Tagozat, \\ Szatmár Egyházmegyei Caritas Szervezetének \\ projekt asszisztense \\ kardos_meli@yahoo.com
}

Az osztálytermi interakciók és a tanári nézetek fontos helyet foglalnak el a hatékony oktatási folyamat megvalósulásában. Jelen tanulmány leírja azon kutatások eredményeit, melyek a nézetekre és osztálytermi interakcióra fókuszálnak. Bemutatja, hogy a kutatásokban együttjárást és eltérést is találtak a tanári nézetek és az osztálytermi interakció között. Az elemzések eredményképpen a szerzö hangsúlyozza, hogy a további kutatásokat a nézetek és a tanári gyakorlat közötti kölcsönös összefüggés szellemében érdemes folytatni.

\section{A pedagógiai nézetek és az oktatási gyakorlat összefüggései}

A mindennapi életben bekövetkező gyors ütemű változás és fejlődés megújulásra képes szakemberek foglalkoztatását és képzését teszi szükségessé. A megújulást elősegítő szemlélet viszont nehézkesen épül be a mindennapi oktatási gyakorlatba. E gyakorlat megváltoztatásának egyik lehetősége a pedagógusok gondolkodásának változása lehetne, melynek első lépése a pedagógusok nézeteinek feltárása. Hercz (2002) szerint a pedagógus gondolkodásának megváltozása elősegítené az iskolai oktatás tartalmának és módszertanának átalakulását is. Ez a megközelítés a szakirodalomban nem egyöntetüen elfogadott, a témát vizsgáló kutatások eredményeiben találhatók bizonyítékok arra, hogy a nézetek összefüggésben vannak a gyakorlattal, és arra is, hogy a nézetek és az osztálytermi gyakorlat eltérnek egymástól. Például Eveyik, Kurt és Made (2009) kutatási eredményeinek elemzése során együttjárást mutattak ki a nézetek és osztálytermi tanári megnyilvánulások között, ellenben Petek (2013) tanulmányának eredményei arra utalnak, hogy az osztálytermi gyakorlatra vonatkozó tanári nézetek és a valós osztálytermi gyakorlat között ellentétek figyelhetőek meg.

E problémát érzékelve fogalmazódott meg, jelen tanulmány központi kérdése, hogy van-e összefüggés a nézetek és a viselkedés között. A témában - amint fent jeleztem - többféle, egymásnak ellentmondó kutatási eredmények is születtek, ezért Richardson (1996) értelmezéséhez hasonlóan, arra helyezzük a hangsúlyt, 
hogy áttekintsük és elemezzük azokat a munkákat, melyek elemzése segítheti a további kutatások irányainak, dimenzióinak árnyaltabb megfogalmazását.

E cél elérése érdekében jelen munkánkban a gazdag, szerte ágazó szakirodalomból olyan tanulmányokat tekintünk át, melyek e probléma értelmezése szempontjából - véleményünk szerint - értékes kutatási eredményeket tartalmaznak. A tanári nézetek és az osztálytermi interakció összefüggéseinek feltárását a vizsgált fogalmak meghatározásával kezdjük, majd áttekintjük azokat a kutatásokat, melyek a nézetek és az osztálytermi gyakorlat kutatására irányultak.

\section{A nézetek különféle értelmezései és a gyakorlat összefüggései}

A szakirodalomban különbözőképpen értelmezik a nézetek (beliefs) fogalmát. Falus (2006) meghatározása szerint a nézet olyan állítás, amelyet a vallója igaznak tart, annak ellenére, hogy nem minden esetben épül valós igazságtartalomra. A nézeteket a tudástól az különbözteti meg, hogy a tudás ismeretelméleti igazolást is feltételez. Hasonló álláspontot képvisel Calderhead (1996) is: „Míg a nézeteken általában vélekedést, elkötelezettséget és ideológiákat, addig a tudáson tényszerü, a szakszerű cselekvést irányító propozíciókat és értelmezéseket értünk." (Calderhead, 1996 idézi Falus, 2006. 26. o.) A nézeteket a szakemberek egy része a tapasztalatokból származó pszichikus konstrukcióknak tekinti, és elismeri, hogy a nézetek szoros összefüggésben állnak a cselekvésekkel, befolyásolják az egyén cselekvéseit (Bárdossy és Dudás, 2011).

A nézetek és a tapasztalat összefüggéseit hangsúlyozza Pajares (1992), megfogalmazása szerint nézeteknek tekinthetőek a tapasztalatokból származó személyes konstrukciók, vagyis az értékek, ítéletek, vélemények, attitüdök, ideológiák, prekoncepciók, feltevések, személyes elméletek. A nézetekre vonatkozó kutatások elemzése során a nézetek tulajdonságaira vonatkozóan kiemeli például azt, hogy viszonylag korán kialakulnak és nehezen változtathatóak, továbbá azt is, hogy a nézetrendszer segíti az egyént abban, hogy definiálja és megértse a világot, illetve saját magát, tehát a nézetek adaptív funkcióval bírnak. Fontos megállapítása még, hogy a nézetek értékelő természetük miatt szürőként segítik az új jelenségek értelmezését, ennek következtében jelentős mértékben befolyásolhatják az egyén viselkedését (Pajares, 1992 idézi Bárdossy és Dudás, 2011).

A felsorolt sajátosságok mellett érdemes a nézetek tartalmának mélyebb, árnyaltabb megismerésére is törekedni. Figyelemre méltó Calderhead áttekintése az 1985-1995 között publikált kutatások eredményeiről. Elemzése szerint a kutatók öt területet találtak, ahol a pedagógushallgatók meghatározó nézetekkel rendelkeztek: 1. a tanulókról és a tanulásról; 2. a tanításról; 3 . a tantárgyról; 4. a tanítás tanulásáról; 5. önmagukról és a tanári szerepröl (Calderhead, 1996 idézi Bárdossy és Dudás, 2011). 
Az előzőekben felsorolt területek közül Al-Amoush és Markic (2011) kutatásukban a tanulásról és tanításról vallott nézeteket vizsgálták kémia szakos tanárjelöltek és tapasztalt kémia tanárok bevonásával. Vizsgálatuk során azt az eredményt kapták, hogy a vizsgálati személyek tradicionális nézetekkel rendelkeznek a tanulással és tanítással kapcsolatosan. Ugyancsak a felsorolt területek közül a pedagógusok önmagukról és a tanári szerepről vallott nézeteit vizsgálta Knoblauch és Chase (2015). Kiemelték, hogy a pedagógusok nézetei önmagukról és a tanári szerepről fontosak az énhatékonyság alakulása szempontjából, az énhatékonyságra vonatkozó hiedelmek pedig kötődnek az attitüdökhöz és a cselekvésekhez. Tschannen-Moran, Woolfolk Hoy és Hoy szerint a tanárok esetében az énhatékonyság érzet tulajdonképpen nem más, mint önnön képességeikről való hiedelmeik az óraszervezéssel és kivitelezéssel kapcsolatban, annak érdekében, hogy sikeresen teljesítsék a specifikus tanítási feladatokat az adott környezetben (Tschannen-Moran, Woolfolk Hoy és Hoy, 1998 idézi Knoblauch és Chase, 2015).

A szociális kognitív elmélet értelmezési keretén belül a tanárok énhatékonyság érzeteit úgy határozhatjuk meg, mint a tanítási helyzetre irányuló énhatékonysággal kapcsolatos hiedelmeket. Bandura szerint az énhatékonysággal kapcsolatos hiedelmek prediktívek a feladat választása, az erőfeszítés, a kitartás és az elért siker szintje szempontjából. E felfogás alapján az oktatási folyamat sikerességét befolyásoló tényezők között hangsúlyos szerepet kap az énhatékonyság érzet kutatása (Bandura, 1977, 1986, 1997 idézi Knoblauch és Chase,2015).

Knoblauch és Chase (2015) empirikus kutatásukban a kezdő tanárok énhatékonyságról vallott hiedelmeit és attribúcióit vizsgálta a tanítási tapasztalatokkal öszszefüggésben. Specifikus figyelmet fordítottak kutatásukban arra, hogy a kutatásba bevont iskolák különböző térbeli elhelyezkedése (vidéki, külvárosi, városi), hogyan változtatja meg a tanárok énhatékonyság érzetét és kauzális attribúcióját. A kutatás eredményei szerint a kontextuális hatások jelentős mértékben befolyásolják a kezdő tanárok hatékonysággal kapcsolatos értékeléseit. A kezdő tanárok esetében a vizsgálat eredményei szerint az énhatékonyság legdöntőbb forrásai a gyakorlatban szerzett jó tapasztalatok voltak (Knoblauch és Chase, 2015). Ez a megállapítás összhangban van Pajares (1992) - előzőekben bemutatott - nézet meghatározásával, melyben a nézetek és a tapasztalat összefüggéseit hangsúlyozza (Pajares, 1992 idézi Bárdossy és Dudás, 2011).

A magyar szakirodalomban Falus Iván tanulmányai (Falus, 2001a; 2001b; 2001c; 2002) adnak részletes áttekintést a nézetekkel kapcsolatos kutatások eredményeiről és kérdésfelvetéseiről. Falus szerint a kutatásokban közös pontként jelenik meg, hogy ,a tanárok rendelkeznek egy többé vagy kevésbé koherens nézetrendszerrel, amely segíti őket a bonyolult jelenségek strukturálásában, megértésében és befolyásolja gyakorlati tevékenységüket." (Falus, 2001a. 23. o.).

Ugyancsak a nézetek és az osztálytermi gyakorlat összefüggéseit kutatta Eveyik, Kurt és Mede (2009). Tanulmányukban egy török származású angol - mint idegen 
nyelv - tanár nézeteit vizsgálták az osztálytermi folyamatok irányításával kapcsolatosan, valamint a nézetek és a valós osztálytermi gyakorlat között megjelenő hasonlóságok és eltérések kutatására is kitértek. Az attitüd és hiedelem vizsgálatára az osztályvezetési skálát (ABCC- Attitudes and Beliefs on Classroom Control) alkalmazták, a tanítási filozófia vizsgálata egy támogatott felidézést alkalmazó ülés keretében zajlott. A kutatásban egy 29 éves tanár vett részt, aki hét éves oktatási tapasztalattal rendelkezett. A kutatás eredményeinek elemzése során együttjárást mutattak ki a kutatásban részt vevő tanár hiedelmei és az osztálytermi interakciókban megjelenő megnyilvánulásai között (Eveyik, Kurt és Mede, 2009).

Kochenderfer-Ladd és Pallatier (2008) tanári nézet és tanulói viselkedés öszszefüggéseit vizsgáló kutatásukban hasonló eredményre jutottak. Munkájukban a következőket vizsgálták: a tanárok gondolkodásmódja befolyásolja-e, hogy a diákok hogyan küzdenek meg az iskolai erőszakkal; milyen esetekben, milyen gyakran jelentik a diákok a tanároknak az iskolában előforduló erőszakos megnyilvánulásokat. Kérdőíves felmérést végeztek, amelyben 34 második és negyedik osztályban tanító pedagógustól és 363 diáktól (188 fiú, 175 lány, átlagéletkor 9 év 2 hónap) gyüjtöttek információkat. A vizsgálat eredményeinek értelmezését követően megállapították, hogy azok a tanárok, akik az erőszakos magatartást a tanulók körében elfogadhatónak tartják, kisebb valószínüséggel avatkoznak be ezeknek a megoldásába, azonban ha az előzőtől eltérő módon gondolkodnak, azaz nem tartják elfogadhatónak az erőszakos megnyilvánulásokat a tanulók körében, sokkal valószínübb, hogy beavatkoznak az összetüzésekbe. A tanári hiedelmek előrevetítették a diákok öszszetüzéseibe való tanári beavatkozások előfordulásának gyakoriságát, amely aztán direkt vagy indirekt módon összefüggésbe került az alacsonyabb szintủ erőszakos megnyilvánulások mértékével. Kochenderfer-Ladd és Pallatier (2008) kutatásának eredményei azokat a felfogásokat erősítették, amelyek szerint a tanári nézetek öszszefüggésben állnak a tanári megnyilvánulásokkal, a nézetek direkt vagy indirekt módon meghatározzák a tanulók viselkedését is.

\section{A nézetek és a gyakorlat közötti eltérések}

A szakirodalomban bár számos kutatás bizonyítja a nézetek gyakorlatra vonatkozó hatását, azonban megjelennek olyan értelmezések is, melyek ellentmondanak annak a megközelítésnek, hogy a nézetek és az osztálytermi gyakorlat sajátosságai összefüggnek.

Petek (2013) tanulmányában a tanárok osztálytermi interakcióról vallott hiedelmei és a tantermi gyakorlata közötti kapcsolatot vizsgálta. A kutatásban félig strukturált interjú és támogatott felidézés technika került alkalmazásra egy nem angol anyanyelvủ és egy angol anyanyelvủ angol tanár esetében. A kutatási eredmények arra utaltak, hogy az osztálytermi gyakorlatra vonatkozó tanári nézetek és a valós osztálytermi gyakorlat között ellentétek figyelhetőek meg. A tanulmány rávilágít a tanárok 
nézetei és az osztálytermi interakciók közötti különbségekre, kiemeli a téma mélyebb kutatásának fontosságát, és felhívja a figyelmet arra, hogy szükség lenne a tanárok tudatossági szintjének növelésére olyan tréningek segítségével, melyek segítik a nézetek és az osztálytermi gyakorlat összehangolását (Petek, 2013).

A tudatossági szint növelése nem biztos, hogy elegendőnek bizonyul a nézetek és osztálytermi interakció összehangolásának erősítésére. Ezt a felfogást árnyalják Norton és társai (2005) kutatási eredményei, amelyek a szándék mint befolyásoló tényező fontosságát is kiemelik a nézetek és osztálytermi gyakorlat közelítésének elérésében. A kutatók megjegyzik, hogy a tanár tanítással kapcsolatos hiedelmei nem feltétlenül azonosak a megvalósításra irányuló szándékaival. Kutatásuk és a tanári cselekvéssel kapcsolatos szakirodalom áttekintése alapján azt találták, hogy a tanárok úgynevezett „,ideális” és „müködő” fogalmakkal rendelkeznek a tanítással kapcsolatosan (Norton és társai, 2005 idézi Riensties, Brower és Lygo-Baker, 2013).

Riensties és társai (2013) kutatásának eredményei rávilágítottak arra, hogy a pedagógusok tanítással kapcsolatos ideális koncepciói nagyban eltértek attól, amit a gyakorlatukban érvényesítettek. A vizsgálatba bevont pedagógusoknak hiedelmei és szándékai lényegesen eltértek attól, amit az osztálytermi gyakorlatukban megjelenítettek. Pontosabban fogalmazva, a vizsgálatba bevont pedagógusoknál szándékaik miatt mutatkozott eltérés hiedelmeik és valós gyakorlatuk között az interaktív tanítás témájában, az osztálytermi munkára vonatkozó professzionális fejlődésben és a tanulók motiválásában. Ennek tükrében indokolt, hogy a pedagógusokat egyaránt biztassuk nézeteik feltárására és a gyakorlatra vonatkozó szándékaik megfontolására. A tanárokat bátorítani kellene arra, hogy vizsgálják meg azt, hogy az oktatási gyakorlatuk milyen mértékben felel meg a hiedelmeiknek, tárják fel, hogy az összefüggés jellege milyen hatással van az elérni kívánt teljesítményre és akarnak-e, illetve min akarnak és hogyan változtatni.

\section{A nézetek és a gyakorlat összefüggései az osztálytermi interakció függvényében}

A szakirodalmat áttekintve egyaránt találunk olyan értelmezéseket, amelyek szerint a tanárok nézete befolyásolja az osztálytermi folyamatokat és ezáltal a tanulók teljesítményét és olyanokat is, amelyek szerint a tanári nézetek nem nyilvánulnak meg az osztálytermi folyamatokban. Ezek az ellentmondó eredmények, illetve megközelítések további vizsgálatok szükségességére hívják fel a kutatói közösség figyelmét. Alaposabb problémafeltáráshoz vezethet, ha mélyebben vizsgáljuk meg az osztályteremben zajló tanulási folyamatokat és e kontextusban megjelenő, illetve értelmezhető összefüggéseket, így a nézetek és az osztálytermi gyakorlat viszonyát is. Ez a megközelítés tehát hangsúlyozza, hogy a nézetek és az osztálytermi gyakorlat összefüggéseit indokolt az osztálytermi interakciók keretén belül kutatni (Riensties, Brower és Lygo-Baker, 2013). 
Az osztálytermi folyamatok mechanizmusainak feltárása lehetőséget adhat az osztálytermi interakciók hatékonyabbá tételére. Az osztálytermi interakciók kutatásának fontosságát és gyakorlati hasznosságát igazolja Ritter és Hancock (2007) tanulmánya, melyben a szerzők kiemelik, hogy a tanárok számára egyik legnagyobb kihívásnak számít az osztálytermi interakciók menedzselése, az osztály vezetése, irányítása, szervezése (classroom management). A tanárok általában úgy határozzák meg az „osztályvezetést”, mint a tanár erőfeszítéseit arra, hogy felügyelje az osztályban zajló tevékenységeket, a tanulási folyamatok alakulását, a szociális interakciókat és a tanulói viselkedések összességét (Burden, 2000; Good és Brophy, 2000; Iverson, 2003; Weinstein, 1996 idézi Ritter, Hancock, 2007). Az osztály vezetésére számos stratégia ismeretes a szakirodalomban, és ezen stratégiák széles körben elérhetőek a tanárok számára. Ritter és Hancock, (2007) tanulmányukban bemutatják Glickman, Tamashiro (1980) és Wolfgang (1995) modelljét, melyben az osztályvezetési stratégiák három típusát különítették el: beavatkozó; nem beavatkozó; interaktív. A beavatkozó stratégia szerint a tanulók úgy tanulják meg a megfelelö viselkedést, hogy a tanár az adott viselkedést jutalmakkal és büntetésekkel erősíti meg. A másik véglet a nem beavatkozó stratégia, mely abból indul ki, hogy a tanulók rendelkeznek belső hajtóerővel, késztetéssel (drive) arra, hogy hatást gyakoroljanak a környezetükre. Ezért a nem beavatkozó pedagógusok szerint engedni kell, hogy a tanulók szabadon megnyilvánuljanak és hatást gyakoroljanak az osztálytermi helyzetekre, a tanároknak pedig nem kell, hogy beavatkozzanak a tanulók viselkedésének irányításába. A két véglet között az interaktív stratégiát vallók szerint a tanuló a külső környezeti ingerekkel, tárgyakkal és emberekkel kapcsolatba kerülve sajátítja el a megfelelő viselkedést. Szerintük a tanulóknak és a tanároknak közösen kell felelősséget vállalni az osztálytermi folyamatok alakulásában, alakításában.

Az osztályok vezetésének, menedzselésének feladata összetett. Magába foglalja a tanár azon erőfeszitéseit, hogy felügyelje az osztályban zajló tevékenységeket, például a tanulási folyamatot, a szociális interakciókat és a tanulók viselkedését.

Ormrod és Vitto kutatásaikban kimutatták, hogy a pedagógusok felismerik az összefüggést az osztály irányítása és a tanulók tanulási eredményei között (Ormrod, 2003; Vitto, 2003 idézi Ritter és Hancock, 2007). Különböző kutatásokban a tanárok azt is jelezték, hogy az osztály irányítása, menedzselése számukra az egyik legállandóbb és legösszetettebb kihívás (Manning és Bucher, 2003; Smith, 2000; Sokal, Smith és Mowat, 2003 idézi Ritter és Hancock, 2007). Ezeket az eredményeket megfontolva, indokolt azoknak a tényezőknek a feltárása, melyek befolyásolják az osztály irányítását az iskolai oktatásban. E faktorok egyike például, hogy a tanárok milyen jellegü képzésben részesültek. Martin és Shoho’s (2000) osztályvezetést vizsgáló kutatásukban egyéni különbségeket fedeztek fel a hagyományos és alternatív képzésben részesülő tanárok között (Martin és Shoho's, 2000 idézi Ritter és Hancock, 2007). Martin és Yin (1999) tanulmányukban a nemek közti kü- 
lönbségeket vizsgálták, melyben azt találták, hogy a nők szignifikánsan kevésbé voltak beavatkozóak, mint férfi társaik az instrukciók adásában és a tanulók irányításában (Martin, Yin, 1997 idézi Ritter és Hancock, 2007). Egy másik tanulmányukban a városban tanító és a falun tanító tanárok közötti osztályvezetési különbségeket kutatták. Azt találták, hogy a városban tanító tanárok szignifikánsan nagyobb mértékben a beavatkozás hívei, mint a falun tanító tanárok, különösen az egyén irányításának tekintetében. A kutatásban arra vonatkozó adatok is találhatóak, hogy a városi tanárok lényegesen beavatkozóbbak a feladatok kiadása (instructional management) során, mint a falusi környezetben tanító tanárok (Martin és Yin, 1999, idézi Ritter és Hancock, 2007).

Martin és Baldwin (1994) a tapasztalat hatását vizsgálva az osztály menedzsment kapcsán arra az eredményre jutottak, hogy a pályakezdő tanárok beavatkozóbbak voltak, mint tapasztalt társaik (Martin és Baldwin, 1994 idézi Ritter és Hancock, 2007). Ugyanakkor Martin és Shoho (2000) azt találták, hogy viselkedés menedzsment (behavior management) tekintetében a tapasztalt tanárok szignifikánsan inkább beavatkozóak voltak, mint kezdő társaik (Martin és Shoho, 2000 idézi Ritter és Hancock, 2007).

Az oktatási stílus és a személyes jellemzők vizsgálatára tért ki longitudinális kutatásban Opdenakker és Van Damme (2006). Több dimenzió mentén vizsgálták matematika tagozatos osztályokban tanító tanároknál a hatékony tanítási gyakorlat és a tanárok személyes jellemzői (nem, végzettség, óravezetési célok és munkával való elégedettség) közötti kapcsolatot. A kutatásban 47 iskola 132 matematika tagozatos osztálya és 78 tanára vett részt. A kutatás eredményei azt mutatták, hogy a hatékony osztálytermi gyakorlat a tanulóközpontú oktatási stílusnak és a jó osztályvezetési képességeknek köszönhető. Továbbá az is kiderült, hogy a magas munkahelyi elégedettségi szinttel rendelkező tanárok több oktatási támogatást biztosítanak diákjaiknak, föként az alacsony képességi szintü tanulóknak, mint azok a tanárok, akiknek a munkával való elégedettségi szintje alacsony (Opdenakker és Van Damme, 2006).

Az osztályvezetési stílus tanulókra gyakorolt hatását vizsgálta Djigic és Stojiljkovic (2011). Kutatásuk célja az osztályvezetési stílus, az osztálybeli hangulat és a diákok teljesítménye közötti kapcsolat feltárása volt. 273 tanító vett részt felmérésükben, amelyben az Osztálytermi Vezetési Stílus Protokoll (PCMSA- Protocol for classroom management styles assessment) eszközt alkalmazták. A vizsgálati adatok azt mutatták, hogy a tanárok és a diákok leginkább akkor elégedettek, ha az osztálybeli hangulat interaktív módon alakul, azaz a tanulók a külső környezeti ingerekkel, tárgyakkal és emberekkel kapcsolatba kerülve sajátítják el a megfelelö viselkedést. A diákok teljesítménye akkor a legmagasabb, amikor a tanárok interaktív stílusban dolgoznak és a legalacsonyabb a beavatkozó stílus esetében (Djigic és Stojiljkovic, 2011). 
Ritter és Hancock (2007) szerint ajánlott megvizsgálni, hogy léteznek-e olyan kulturális vagy akár etnikai különbségek a tanári nézetekben, amelyek befolyásolják az osztálytermi interakciókat.

Ebben a témakörben érdemes megemlíteni Namrata (2011) kutatásának eredményeit. A kutatás célja az volt, hogy feltárja a tanárok hátrányos helyzetü gyerekekre vonatkozó hiedelmeit és elvárásait. A kutatásba véletlenszerủ mintavétel alapján került be nyolc állami iskola és 35 tanár. A kutatás során strukturált interjút és viselkedés megfigyelést alkalmaztak természetes osztálytermi környezetben. A kutatási eredmények azt mutatták, hogy az általános iskolai tanárok negatív értelemben eltérő bánásmódban részesítik a hátrányos helyzetű csoportból származó gyermekeket az osztálytermi környezetben. A legtöbb tanár negatívan észleli ezeket a gyermekeket és ehhez kapcsolódóan nincsenek a tanulók tanulási sikereire vonatkozóan pozitív elvárásaik (Namrata, 2011).

A magyar nyelvű szakirodalomból kiemelhető Sallai Éva (2009) egyik munkája, amelyben egy 30 órás programot mutatott be a hátrányos helyzetü tanulók iskolai sikerességének növelésére a professzionális tanári kommunikációra alapozva. Kiemelkedően fontosnak tartja a szerző, hogy a pedagógusképzés során jelentős figyelmet kapjon a tanári kommunikáció. A professzionális tanári kommunikáció - benne a feltétel nélküli elfogadás, a pozitív odafordulás attitüdje - feltétele a hátrányos helyzetủ tanulókkal való jó kapcsolat kialakításának, amely viszont meghatározza a diákok tanulmányi eredményességét is.

\section{A nézetek és a gyakorlat összefüggéseit vizsgáló kutatási eredmények összefoglalása}

Összefoglalva a tanári nézetek és az osztálytermi folyamatok kutatására irányuló tanulmányok eredményeit az alábbi következtetéseket fogalmazhatjuk meg:

- A pedagógusok nézetei önmagukról és a tanári szerepről fontosak az énhatékonyság alakulása szempontjából, az énhatékonyságra vonatkozó hiedelmek pedig kötődnek az attitüdökhöz és a cselekvésekhez. Az énhatékonysággal kapcsolatos nézetek egyaránt hatást gyakorolnak a feladat választására, az erőfeszítésre, a kitartásra és az elért siker szintjére. Ennek értelmében az énhatékonyság érzet kutatásának az oktatási folyamat sikerességét befolyásoló tényezők között hangsúlyos szerepe van, ti. meghatározza az osztálytermi interakciót (Bandura, 1977, 1986, 1997 idézi Knoblauch és Chase, 2015).

- A tanári nézetek összefüggésben állnak a tanári megnyilvánulásokkal és ez direkt vagy indirekt módon meghatározza a tanulók megnyilvánulásait is (Kochenderfer-Ladd és Pallatier, 2008). 
- A tanárok nézetei és az osztálytermi interakciók között különbségek találhatók, ez pedig felhívja a figyelmet a téma további alaposabb kutatásának szükségességére (Petek, 2013).

- A tanár tanítással kapcsolatos hiedelmei nem feltétlenül azonosak az erre irányuló szándékaival. A tanári cselekvéssel kapcsolatos szakirodalom áttekintése után Norton és társai (2005) azt találták, hogy a tanárok úgynevezett „ideális” és „müködő” fogalmakkal rendelkeznek a tanítással kapcsolatosan. Riensties és társai (2013) kutatásának eredményei rávilágítottak arra, hogy a pedagógusok tanítással kapcsolatos ideális koncepciói jelentősen eltértek attól, amit gyakorlatba átültettek (Riensties, Brower és Lygo-Baker, 2013).

- A hatékony óravezetés szignifikánsan hozzájárul a tanuló hatékony tanulásához és fejlődéséhez (Ritter és Hancock, 2007).

A különböző kutatások áttekintése megerősítette, hogy a tanulmány központi kérdésére, a nézetek és a gyakorlat közötti kapcsolat árnyalt megismerésére, feltárására, Richardson (1996) értelmezése alapján ajánlott választ keresni, mely szerint: „A nézetek meghatározzák a cselekedeteket, de a cselekedetekben szerzett tapasztalatok és reflexiók visszahatnak a nézetekre, ezáltal okozva változást és/vagy gyarapodást." (Richardson, 1996. 103. o. idézi Bárdossy és Dudás, 2011. 9. o.). Tehát feltételezhetjük, hogy a nézetek és a cselekedetek kölcsönösen hatnak egymásra, vagyis a nézetek formálhatják a viselkedést, ugyanakkor a cselekedetek értelmezése és megváltoztatása hathat a nézetek megváltoztatására is.

\section{Irodalom}

Al-Amoush, S. A. és Markic, S. (2011): Jordanian prospective and experienced chemistry teachers' beliefs about teaching and learning and their potential role for educational reform. Science Education International, 3. sz. 185-201.

Bárdossy Ildikó és Dudás Margit (2011): Pedagógiai nézetek. Kódex Nyomda, Pécs.

Djigic, G. és Stojiljkovic, S. (2011): Classroom management styles, classroom climate and school achievement. Procedia - Social and Behavioral Sciences, 29. sz. 819-828.

Eveyik, A. E., Kurt, G. és Made, E. (2009): Exploring the relationship between teacher beliefs and styles on classroom management in relation to actual teaching practices: a case study. World Conference on Educational Sciences, Nicosia, North Cyprus, New Trends and Issues in Educational Sciences, 1. sz. 612-617.

Falus Iván (2001a): Pedagógus mesterség - pedagógiai tudás. Iskolakultúra, 2. sz. 21-28.

Falus Iván (2001b): A gyakorlat pedagógiája. In: Golnhofer Erzsébet - Nahalka István (szerk.): A pedagógusok pedagógiája. Nemzeti Tankönyvkiadó, Budapest. 15-27.

Falus Iván (2001c): Gondolkodás és cselekvés a pedagógus tevékenységében. In: Báthory Zoltán - Falus Iván (szerk.): Tanulmányok a neveléstudomány köréböl 2001. Osiris Kiadó, Budapest, 213-234. 
Falus Iván (2002): A tanuló tanár. Iskolakultúra, 6-7. sz. 76-80.

Falus Iván (2005): A tanári tevékenység és a pedagógusképzés új útjai. Müszaki Könyvkiadó, Budapest.

Falus Iván (szerk., 2006): A tanárrá válás folyamata. Gondolat Kiadó, Budapest.

Hercz Mária (2002): A szakképzésben dolgozó tanárok gondolkodása tanítványaik kognitív fejlődéséről. Társadalom és Gazdaság, 2. sz. 251-269.

Knoblauch, D. és Chase, M. A. (2015): Rural, suburban, and urban schools: The impact of school setting on the efficacy beliefs and attributions of student teachers. Teaching and Teacher Education, 45. sz. 104-114.

Kochenderfer-Ladd, B. és Pallatier, M. E. (2008): Teachers' views and beliefs about bullying: Influences on classroom management strategies and students' coping with peer victimization'. Journal of School Psychology, 46. sz. 431-453.

Namrata. (2011): Teachers' beliefs and expectations towards marginalized children in classroom setting: A qualitative analysis. Procedia - Social and Behavioral Sciences, 15. sz. 850-853.

Opdenakker, M. C. és Van Damme, J. (2006): Teacher characteristics and teaching styles as effectiveness enhancing factors of classroom practice. Teaching and Teacher Education, 22. sz. 1-21.

Petek, E. (2013): Teacher's Beliefs about Classroom Interaction and their Actual Practices: A Qualitative Case Study of a Native and a Non-native English Teacher's In-class Applications. Procedia - Social and Behavioral Sciences, 70. sz. 1195-1199.

Richardson, V. (1996): The Role of Attitudes and Beliefs in Learning to Teach. In: Sikula, J. (szerk.): Handbook of Research on Teacher Education. MacMillan, New York. 102-119.

Riensties, B., Brower, N. és Lygo-Baker, S. (2013): The effects of online professional development on higher education teachers'beliefs and intentions towards learning facilitation and technology. Teaching and Teacher Education, 29. sz. 122-131.

Ritter, J. T. és Hancock, D. R. (2007): Exploring the relationship between certification sources, experience levels, and classroom management orientations of classroom teachers. Teaching and Teacher Education, 23. sz. 1206-1216.

Sallai Éva (2009): Módszerek a hátrányos helyzetü tanulók iskolai sikerességének segítésére. Educatio Társadalmi Szolgáltató Nonprofit Kft., Budapest. 